Plant Tissue Cult. \& Biotech. 17(2): 149-159, 2007 (December)

\title{
Bacteriophage Lambda Genomic Library Construction of Oryza sativa L. var. Pokkali
}

\section{Suhaila Rahman ${ }^{1}$,Masa-aki Ohto, Zeba I Seraj ${ }^{* 1}$ and Eduardo Blumwald}

Department of Plant Sciences, University of California, Davis, CA, USA

Key words: Rice, Pokkali, Genomic library, Lambda vector, Partial Fill-In, Titer

\begin{abstract}
A major QTL called 'Saltol' on rice chromosome 1 has been identified as linked to salinity tolerance traits of the landrace, Pokkali. A genomic library of Pokkali rice variety was constructed in bacteriophage Lamda Fix II with $20 \mathrm{~kb}$ inserts. Plaques containing genes implicated to salt tolerance have been identified using probes homologous to S-Ad methionine synthetase (SAM) and cation chloride co-transporter after two rounds of hybridization. Clearly demarcated plaques of the two clones of interest have been lifted out for DNA isolation and subsequent characterization to be followed by subcloning into TAC vectors for Agrobacterium-mediated transformation of large genomic fragments into sensitive rice.
\end{abstract}

\section{Introduction}

Rice is the most important food crop of the world (Cantrell and Reeves 2002). The production of rice should increase by at least $40 \%$ in the next 25 years to keep pace with the growing world population. Minimization of the loss caused by biotic and abiotic environmental factors not only can help improve net production but extend rice cultivation in marginal and noncultivable lands (Tyagi and Mohanty 2000, Khush 1999). In Bangladesh, out of a total cultivable area of nine million ha, about one million hectares in the coastal area is affected by salinity, which is more pronounced during the dry season (Lisa et al. 2004). Traditional breeding approaches have been inefficient principally due to the difficulty of (a) recovering elite genotypes with salt tolerance traits, (b) the genetic complexity of salt tolerance and (c) the strength of genotype $\times$ environment interactions.

There are very few donors for salt tolerance traits in rice genotypes, including wild rice. Among lowland rice genotypes, the indica varieties, Pokkali and Nona Bokra are classified as highly tolerant on the basis of various physiological parameters (Akbar et al. 1986a). Genetic studies have revealed that

*Corresponding author. E-mail: zseraj@yahoo.com ${ }^{1}$ Rice Research and Biotechnology Laboratory, Department of Biochemistry and Molecular Biology, University of Dhaka, Dhaka-1000, Bangladesh. 
salt tolerance of these two varieties is principally due to additive gene effects (Akbar et al. 1986b). The Pokkali cultivar is highly salt-tolerant and low-yielding despite producing vigorous seedlings (Senadhira et al. 1994) and is commonly grown in coastal areas of Kerala, India. It is a traditional, tall, photoperiodsensitive rice cultivar that is susceptible to lodging and has low tillering capacity and long, broad, dark green and droopy leaves. The leaves senesce quickly after flowering. The grain has red pericarp and poor cooking quality (Gregorio et al. 2002). Photosynthesis, stomatal conductance, and transpiration were measured for Pokkali and IR29 seedlings after addition of $150 \mathrm{mM} \mathrm{NaCl}$. Photosynthesis decreased within minutes and stabilized within $30 \mathrm{~min}$ at one tenth of the prestress level in Pokkali. The decrease was paralleled by decreased stomatal conductance and transpiration rates, indicating limited $\mathrm{CO}_{2}$ assimilation due to stomatal closure. According to Kawasaki et al. (2001) under long term salt stress, Pokkali continued to grow at a low photosynthetic rate; after seven days of salt stress, plant biomass had approximately doubled.

Some progress has been made to transfer salinity tolerance from traditional donors such as Pokkali to modern high yielding varieties, but the complexity of the trait has proven challenging to breeders (Gregorio et al. 2002, Flowers and Flowers 2005). Since most of the tolerant landraces are low-yielding varieties with numerous undesirable traits, a novel breeding approach is needed to rapidly transfer high levels of tolerance of landraces into high yielding breeding lines while at the same time avoiding negative linkage drag (Young and Tanksley 1989). Marker-assisted breeding (MAB) has been recently adopted to improve the power and efficiency of breeding programs. Introgression of salt tolerance traits of Pokkali (subspecies indica) into popularly grown indica varieties of South and South-East Asia is difficult even with MAB, because of extremely low marker polymorphism. These difficulties could be overcome by the use of gene-based or gene-flanking markers.

A major QTL designated 'Saltol' was mapped on chromosome 1 using a population generated from a cross between the sensitive rice variety IR29 and the tolerant landrace, Pokkali. This QTL accounted for more than $40 \%$ of the variation in salt uptake in this population (Bonilla et al. 2002). Subsequent results from our laboratory have shown that a large $5 \mathrm{cM}$ region of the rice chromosome 1 is linked to salinity tolerance traits (Elahi et al. 2004) such as low $\mathrm{Na}^{+} / \mathrm{K}^{+}$ratio. This ratio has been correlated positively with salt tolerance (Bohra and Dorffling 1993, IRRI 1996, Lee et al. 2003). Many genes in the saltol loci have the potential to confer salt tolerance, for example, homologues of the SKC1 gene identified in Nona Bokra (Ren et al. 2005), the cation-chloride co-transporter, stress-inducible membrane pore protein, universal stress protein ER6, Myb-like transcription factor, methionine synthetase, protein kinase, etc. (Thomson et al. 2007). 
These genes could be targeted for designing gene-based markers. It would also be useful to be able to obtain clones of these genes for direct transformation into sensitive varieties to see their effect on conferring salt tolerance. Therefore, the current work describes successful production of a genomic library of Pokkali and identification of specific clones in the Saltol locus. The bacteriophage lambda vector used contained a Not I site, so that if necessary, genes with their promoters could be sub-cloned into the transformation-competent binary vector TAC (Qu et al. 2003) for insertion of large fragments into sensitive rice cultivars.

\section{Materials and Methods}

The accession number of Oryza sativa L. var. Pokkali used was: IRGS \# 108921, tolerance score 5 (provided by IRRI). Stratagene Lambda Kit used was: (a) Lambda FIX® II/Xho I Partial Fill-In Vector Kit. Catalogue \#248712 (Xho I/Gigapack ${ }^{\circledR}$ III XL Packaging Extract) and (b) Klenow Fill-In Kit (Catalogue \#200410).

Preparation of the insert DNA: About 4 - 6 gm leaf tissues were ground in liquid nitrogen and high molecular wt. DNA $(\sim 30-50 \mathrm{~Kb})$ of Pokkali isolated by the CTAB method (Doyle and Doyle 1990), with some modifications). After precipitation of the DNA in ice cold isopropanol, long strings of DNA were spooled out to obtain high molecular wt. DNA. Each step was handled very gently to avoid shearing of DNA.

Partial digestion was successfully done with Sau3A according to the Stratagene manual with some modifications. Pilot digestion was performed with small amount of DNA to optimize the enzyme concentration and for the pilot reaction, $2.5 \mu \mathrm{g}$ of DNA were mixed with $10 \times$ NEB Sau3A 1 buffer, $10 \mathrm{mg} / \mathrm{ml}$ BSA and $0.1 \mathrm{U} / \mu \mathrm{l}$ Sau3A enzyme in several tubes. The digestion was incubated at $37^{\circ} \mathrm{C}$ for $10,20,30,40,50$ and 60 minutes. To stop the digestion reaction, loading dye (containing EDTA and SDS) was added. The full scale digestion was carried out with $50 \mu \mathrm{g}$ DNA in 10 to 15 tubes, each containing $5 \mu \mathrm{g}$ of DNA (Fig. 1) and $2 \times$ of all digestion components compared to the pilot reaction.

Pulse field gel electrophoresis was used to check the partial digestion products of $9-23 \mathrm{~kb}$ in 1\% agarose gel (Bio-Rad Chef DRTM 1ll-chiller). PFGR run conditions were: Pumping 80; Initial Pulse, 5 sec; Final Pulse, 15 sec; Volt, $5 \mathrm{~V} / \mathrm{cm}$; Run time, $16 \mathrm{~h}$; and Pumping temperature $14^{\circ} \mathrm{C}$.

In order to ligate the digested insert DNA to the Lambda Fix II vector, it was important to fill-in the first two nucleotides which was carried out using Stratagene's Klenow Fill-In kit. Pooled $50 \mu$ g genomic insert DNA was purified by ethanol precipitation after partial digestion, mixed with $10 \times$ fill-in buffer $(60$ $\mathrm{mM}$ Tris- $\mathrm{HCl}: \mathrm{pH} 7.5,60 \mathrm{mM} \mathrm{NaCl}, 60 \mathrm{mM} \mathrm{MgCl} 2,0.5 \%$ gelatin, $10 \mathrm{mM}$ dithiothreitol, DTT), $10 \mathrm{mM}$ dATP, $10 \mathrm{mM}$ dGTP, 5U/ $\mu$ l Klenow enzyme and, 
incubated at $22^{\circ} \mathrm{C}$ for the partial fill-In reaction. The mixture was dissolved in $10 \times$ STE buffer $(1 \mathrm{M} \mathrm{NaCl}, 200 \mathrm{mM}$ Tris-HCl: $\mathrm{pH}$ 7.5, $100 \mathrm{mM}$ EDTA) and then purified with phenol-chloroform and ethanol precipitation. DNA was then dissolved in $25 \mu \mathrm{l}$ TE Buffer (10 mM Tris-HCl: pH 7.5, 1 mM EDTA).

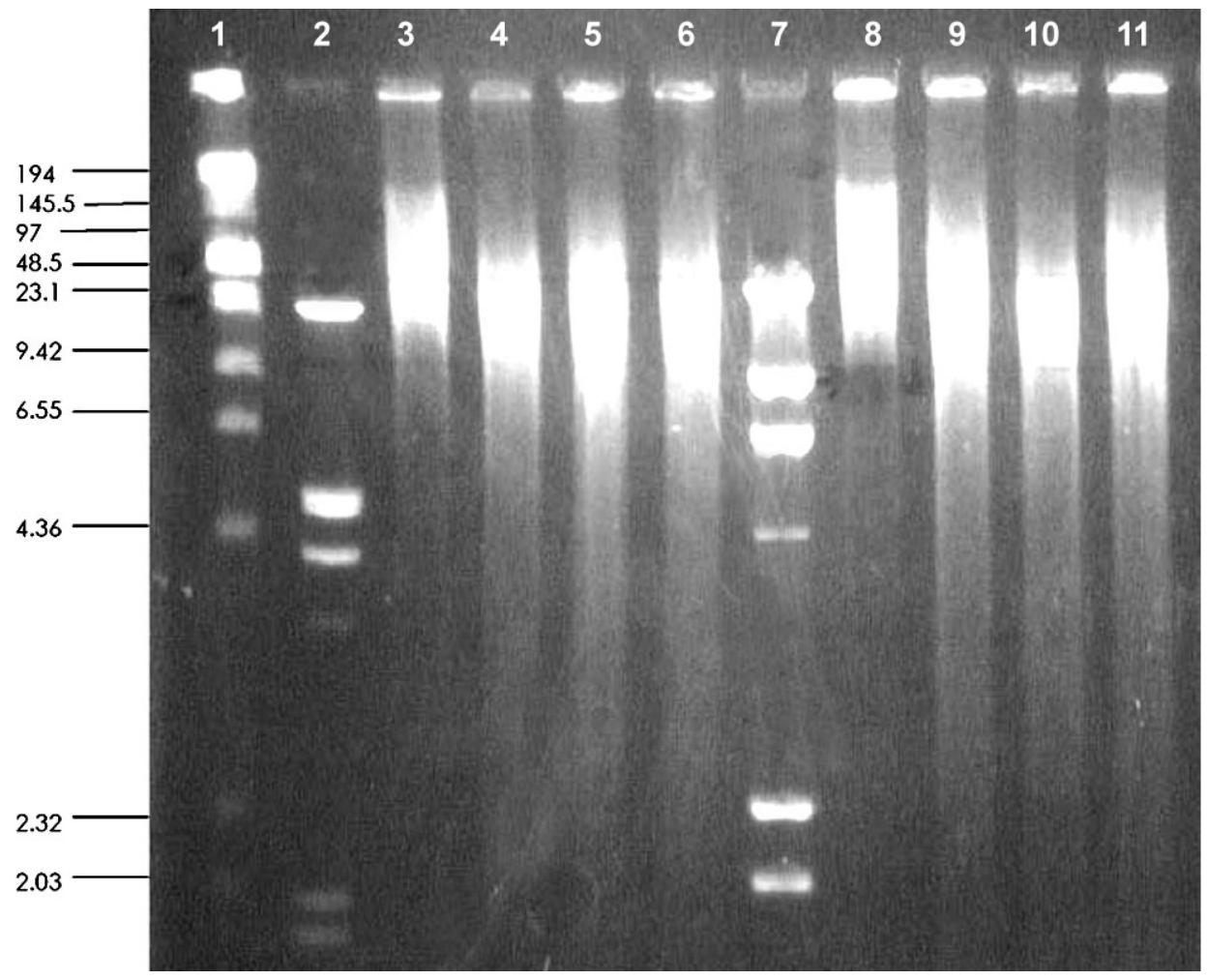

Fig. 1. Optimization of partial digestion of 5 and $10 \mu \mathrm{g}$ DNA by PFGE system. Lane 1: Low range PFGE marker, NEB. Lane 2: Lambda Hind 1ll, EcoRl marker. Lane 3: $5 \mu \mathrm{g}$ Undigested DNA. Lanes 4-6: $5 \mu \mathrm{g}$ digestion at 20, 30, $40 \mathrm{~min}$ time point. Lane 7: Lambda Hind 111 marker. Lane 8: $10 \mu \mathrm{g}$ undigested DNA. Lanes 911: $10 \mu \mathrm{g}$ DNA digestion at 20, 30, 40 min time point.

Ligation of the insert DNA to lambda Phage DNA: It is suitable to clone large fragments of genomic DNA in Lambda Fix II replacement vector (Fig. 2). The Lambda Fix II system takes advantage of spi (sensitive to P2 inhibition) selection and only recombinant phages can grow on the XL1-Blue MRA (P2) strain (Stratagene manual). The first two nucleotides of the Xho I-predigested Lambda Fix II vector was already filled in with dCTP and dTTP, leaving 3'-CT-5' overhangs.

An equal molar ratio of the Sau3A-digested insert was used with the Lambda Fix II vector. To ligate $20 \mathrm{~kb}$ inserts to the lambda vector, $0.4 \mu \mathrm{g}$ of insert for 
every $1 \mu \mathrm{g}$ of vector was used. The ligation mixture contained $1.0 \mu \mathrm{l}$ of the Lambda Fix II vector, $0.4 \mu \mathrm{g}$ insert, $0.5 \mu \mathrm{l}$ of $10 \times$ ligase buffer (New England Biolabs, Inc.), $0.5 \mu \mathrm{l}$ of T4 DNA Ligase (20,000 Units, NEB), up to $5 \mu \mathrm{l}$ with $\mathrm{ddH}_{2} \mathrm{O}$. The ligation was incubated at $16^{\circ} \mathrm{C}$ overnight.

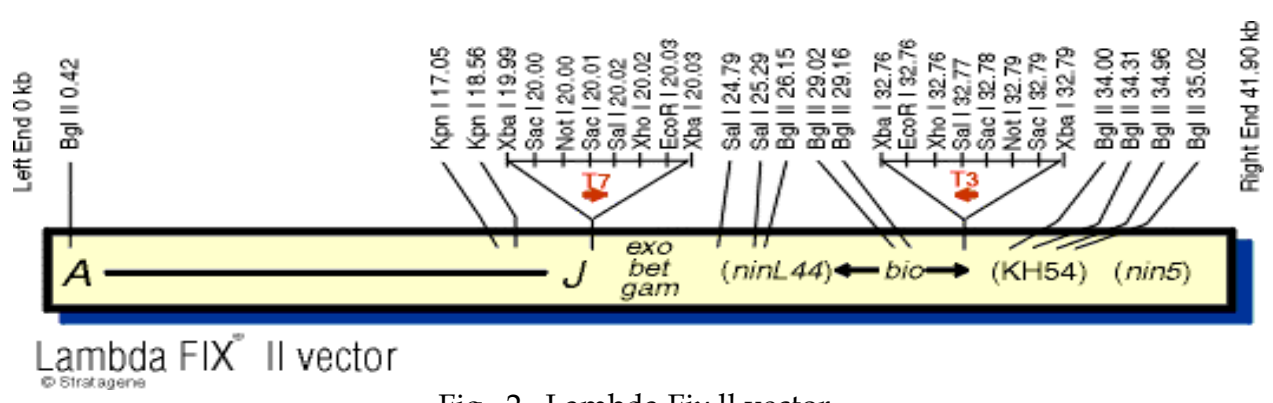

Fig. 2. Lambda Fix 11 vector.

Packaging: The recombined DNA was packaged using Stratagene Gigapack III XL packaging extract, which is a size-selective packaging extract for fragments around $20 \mathrm{~kb}$. In the packaging extract $2.5 \mu \mathrm{l}$ of the ligated DNA was added and gentle pipetting done. The tube was incubated at room temperature $\left(22^{\circ} \mathrm{C}\right)$ for 1.5 to $2 \mathrm{~h}$ after which $500 \mu \mathrm{l}$ of SM buffer $\left(5.8 \mathrm{~g}\right.$ of $\mathrm{NaCl}, 2.0 \mathrm{~g}$ of $\mathrm{MgSO}_{4} .7 \mathrm{H}_{2} \mathrm{O}, 50.0$ $\mathrm{ml}$ of $1 \mathrm{M}$ Tris- $\mathrm{HCl}$ : $\mathrm{pH} 7.5,5.0 \mathrm{ml}$ of $2 \%$ gelatin, $\mathrm{ddH}_{2} \mathrm{O}$ up to 1 liter) was added. $20 \mu \mathrm{l}$ chloroform were added to prevent growth of other bacteria and the tube centrifuged. The supernatant containing the phage was ready for titering. The tube was stored at $4^{\circ} \mathrm{C}$.

Transfection: The recombinant lambda phages can grow only in strains lysogenic for P2 such as XL1-Blue MRA (P2). The bacterial glycerol stock was used to streak NZY agar plates according to the manual and incubated overnight at $37^{\circ} \mathrm{C}$. Bacteria from a single colony were needed to obtain log phase culture and bacteria pelleted and re-suspended with $10 \mathrm{mM} \mathrm{MgSO}_{4}$ according to the manual and used immediately.

Different dilutions i.e. 1 : $100\left(10^{-2}\right), 1: 10000\left(10^{-4}\right), 1: 1000000\left(10^{-6}\right)$ and 1 : $100000000\left(10^{-8}\right)$ of the final packaged reaction in SM buffer were prepared. From each dilution $10 \mu \mathrm{l}$ of packaging extract was added to $200 \mu \mathrm{l}$ of bacterial cells. The phage and the bacterial mix were incubated together at $37^{\circ} \mathrm{C}$ for $15-20 \mathrm{~min}$ to allow the phage to attach to the cells and inject DNA. 3 - $3.5 \mathrm{ml}$ of NZY top agar (NZY broth with $0.7 \%$ agarose) $\left(48^{\circ} \mathrm{C}\right)$ were added to each culture tube and the mixture was poured onto NZY agar-rich plates, which were incubated at $37^{\circ} \mathrm{C}$ until plaques appeared. Each plaque contained phages derived from a single infecting phage. 
The concentration of the phage lysate was determined in number of $\mathrm{pfu} / \mathrm{ml}$ (pfu-plaque forming unit) from plates labeled according to the dilution. The formula used to determine the titer was:

$$
\frac{(\text { Number of plaques }(\mathrm{pfu}) \times \text { Dilution factor }) \times 1000 \mu \mathrm{l} / \mathrm{ml}}{\text { Volume plated }(\mu \mathrm{l})}
$$

Library amplification and plating: The titer of the library was determind to know how much volume of the library could be plated on one large plate. From the titer it was calculated that $85 \mu 1$ of packaged library with $400 \mu$ l host bacteria and $6 \mu$ top agarose would yield $5 \times 10^{4}$ pfu $(40,000-50,000$ plaques) per large plate. Five large plates were required to plate out the whole library to cover the whole rice genome of $450 \mathrm{Mb}$ at least three - four times. Therefore, the whole library was amplified by the host bacteria XL1-Blue MRA (P2) once in five large $150 \mathrm{~mm}$ plates.

Each large plate was labeled with a designation; i.e., 1, 2, 3, 4, 5. The plates were chilled at $4^{\circ} \mathrm{C}$ for around two hours to one day. This helped keep the layer of top agarose from being removed from the plate's agar layer when the filter membranes were peeled off. A series of $150 \mathrm{mM}$ Hybond $\mathrm{N}$ filters were labeled in pencil using gloved hands with the same designation as the plates. Care was taken to avoid bubbles under the filter disc. The membranes were marked asymmetrically by poking three holes through the membrane into the agar using permanent India ink. After 1 - $2 \mathrm{~min}$, a pair of blunt ended forceps were used to peel the membrane from the plate. These membranes were allowed to dry for 15 min to $1 \mathrm{~h}$ on Whatman filter paper (facing plaque side up). Another membrane was plaque lifted in the same way from the same plate (designated \#1B), which was a replica of the first membrane. The ink mark of the replica was in the same asymmetric direction as the first membrane.

Hybridization: Three solutions were used for washing of membranes after air drying, denaturation solution $(1.5 \mathrm{M} \mathrm{NaCl}, 0.5 \mathrm{M} \mathrm{NaOH})$, neutralization solution $(1.5 \mathrm{M} \mathrm{NaCl}, 0.5 \mathrm{M}$ Tris-HCl: pH 8.0), buffer solution (2 × SSC). Each membrane was incubated and processed in a stepwise fashion; i.e., denaturation 2-5 min, neutralization 2 - 5 min and $2 \times$ buffer solution 2 - 5 min with occasional gentle shaking. For each membrane fresh solution was used. After washing, the membranes were dried again and placed on a piece of paper toweling, wrapped in aluminium foil, before crosslinking the DNA on to the membranes using a UV crosslinker.

Two probes were used to screen the genomic library. The probes were: (a) cation chloride co-transporter (475 bp) and (b) S-Ad methionine synthetase (SAM) $(500 \mathrm{bp}$ ). Primer sequences of cation chloride co-transporter (were: forward: 5'-GTGAGGGATGGAGGATTGAT and reverse: 5'-GTGCCTAGGA TAGTA GCG TTC). Primer sequences of SAM (were: forward: 5'- 
ATCTCCACCCA GCACGA TGA and reverse: 5'-AAGCCGCCGTCTTCAGG TAG). Primers for these probes were designed from the Nipponbare database sequence. These probes were used to amplify Pokkali DNA by PCR and sequenced for confirmation of the right product.

The PCR product of cation chloride co-transporter was used as a probe to hybridize the whole library at first. The membranes were washed at room temperature by using $2 \times$ SSC buffer one by one in a plastic Rubbermaid container. Two membranes were hybridized in one hybridization cylinder in a volume of $20 \mathrm{ml}$. Hybridization solutions and incubation temperatures are described in Table 1.

Table 1. Hybridizationn solutions, incubation time and temperature.

\begin{tabular}{llll}
\hline \multicolumn{4}{c}{ Hybridization solutions } \\
\hline Stock solutions & Pre-pre-Hyb (1 liter) & Pre-Hyb $(400 \mathrm{ml})$ & $\mathrm{Hyb}(200 \mathrm{ml})$ \\
\hline Formamide & - & $200 \mathrm{ml}(50 \%)$ & $100 \mathrm{ml}(50 \%)$ \\
SSC $(20 \times)$ & $250 \mathrm{ml}(5 \mathrm{x})$ & $100 \mathrm{ml}(5 \mathrm{x})$ & $50(5 \times)$ \\
Na-phosphate buffer & $\ldots$ & $20 \mathrm{ml}(50 \mathrm{mM})$ & $4 \mathrm{ml}(20 \mathrm{mM})$ \\
pH 7.2 $(1 \mathrm{M})$ & & & \\
Denhardt's $(50 \times)$ & $\ldots$ & $40 \mathrm{ml}(5 \mathrm{x})$ & $4 \mathrm{ml}(1 \times)$ \\
SDS $(10 \%)$ & $50 \mathrm{ml})$ & $2 \mathrm{ml}(0.1 \%)$ \\
Dextran sulfate & $\ldots$ & $\ldots$ & $20 \mathrm{~g})$ \\
ddH ${ }_{2} \mathrm{O}$ & $700 \mathrm{ml}$ & $32 \mathrm{ml}$ & $\mathrm{Up} \mathrm{to} 200 \mathrm{ml}$ \\
Incubation temp. & $60^{\circ} \mathrm{C}$ & $42^{\circ} \mathrm{C}$ & $42^{\circ} \mathrm{C}$ \\
Incubation time & $1 \mathrm{~h}$ & Overnight & Overnight \\
\hline
\end{tabular}

One $\mu \mathrm{l}$ cation chloride co-transporter DNA (100 ng/ $\mu \mathrm{l})$ was mixed with $24 \mu \mathrm{l}$ of $\mathrm{ddH}_{2} \mathrm{O} .10 \mu \mathrm{l}$ random oligonucleotide (Stratagene kit) were added and then heated at $95^{\circ} \mathrm{C}$ for 5 minutes. This was chilled on ice for $2 \mathrm{~min}$ and $10 \mu \mathrm{l}$ of dCTP $5 \times$ buffer and $1 \mu \mathrm{l}$ of Klenow enzyme added. Finally $5 \mu \mathrm{l}$ of ${ }^{32} \mathrm{P}$ dCTP $(50 \mu \mathrm{Ci})$ were added carefully. The tubes were incubated for $15 \mathrm{~min}$ at $37^{\circ} \mathrm{C}$ and then heated up to $95^{\circ} \mathrm{C}$ for $5 \mathrm{~min}$ and added immediately to the cylinder containing hybridization solution for incubation at $42^{\circ} \mathrm{C}$ overnight.

Hybridization solution was discarded in an appropriate ${ }^{32} \mathrm{P}$ radioactive waste container. Membranes were washed with low stringency solution ( $2 \times$ SSC $+0.1 \%$ SDS) three - four times, each wash for $15-30 \mathrm{~min}$ at room temperature. Then with high stringency solution $(0.2 \times$ SSC $+0.1 \%$ SDS) twice at room temp, each wash 30 minutes. After washes, membranes were placed in saran to wrap by avoiding any wrinkle. These packed membranes were placed inside the film cassette overnight.

Phosphor image scanner system was used to scan the membranes. Duplicate membranes were compared to confirm a positive plaque. Only those plaques 
were picked that showed convincing hybridization signals on both sets of membranes. The same membranes were stripped to remove the radiolabeling of previous probes for subsequent with the SAM probe.

Stripping: $1500 \mathrm{ml}$ of $0.1 \%$ SDS were boiled for $1 \mathrm{~h}$. Each membrane was boiled for $10 \mathrm{~min}$ and dropped into the $2 \times$ SSC solution. After proper rinse the membranes were placed in Saran wrap to check the radioactivity. The membranes were pre-hybridized and hybridized with SAM probe as above.

Primary screening results of both probes were confirmed by positioning both replicas of the same plate. The area of positive plaque was picked by using the end of a glass-made Pasteur pipette and lifting 10 to 15 plaques because the plaques were very dense. The agar was dissolved in $1 \mathrm{ml} \mathrm{SM}$ buffer. After addition of $50 \mu \mathrm{l}$ of chloroform, the tubes were shaken at room temperature for 1 - $2 \mathrm{~h}$. These plaques were stored at $4^{\circ} \mathrm{C}$ and then used for secondary screening.

For secondary screening the isolated plaques were transfected with the host bacteria, and the titer determined. An appropriate amount of phage was used to obtain 200 to 300 plaques in one small Petri dish $(100 \mathrm{~mm})$. After secondary screening, phosphor image result of both replicas was compared to detect the truly positive plaques. These were picked and placed in individual tubes and chloroform was added.

\section{Results and Discussion}

DNA isolation: For the genomic library construction high molecular weight DNA isolation of $20-22 \mathrm{~Kb}$ was very crucial since that is the insert accommodation range of the Lambda Fix II vector. For this purpose isolation of string-like DNA was ensured.

Pulse field gel (PFGE) system for size estimation: Accurate size of the isolated DNA could not be estimated by agarose gel electrophoresis which stained in an area from $20-23 \mathrm{~Kb}$. This DNA was actually found to be $40-50 \mathrm{~Kb}$ when run on a PFGE system (Fig. 1). After partial digestion the correct size DNA of 9 - $23 \mathrm{~Kb}$ was obtained after $40 \mathrm{~min}$ of digestion with Sau3A. On agarose this was misestimated as $10 \mathrm{~min}$ only. Therefore, without the PFGE system the correct detection of the digested DNA was not possible.

Ligation: Genomic library construction depends on efficient ligation. Since successful ligation can only be determined after infecting the phages with the host bacteria, higher the number of $\mathrm{pfu} / \mathrm{ml}$ of the library, higher the efficiency of ligation. Using NEB T4 ligase enzyme and buffer resulted in a titer of $3 \times 10^{5}$ to $1 \times 10^{6} \mathrm{pfu} / \mathrm{ml}$, which was high, whereas the Stratagene T4 ligase, buffer and rATP showed only $8 \times 10^{4} \mathrm{pfu} / \mathrm{ml}$.

Packaging: Packaging extracts were used to package recombinant lambda phage with high efficiency. Ligations were carried out at DNA concentrations of 
$0.2 \mu \mathrm{g} / \mathrm{ul}$ or more, which favors concatemers and efficient packaging. Care was taken ensuring that the plaque forming units were the same for every dilution. The titer of plaques of Pokkali library was around $3 \times 10^{5}$ to $1 \times 10^{6} \mathrm{pfu} / \mathrm{ml}$ in different tubes with the same ligation product.

Primary screen result of cation chloride co-transporter: The whole genomic library was amplified and plated in five large plates $(150 \mathrm{~mm})$. After screening replicas of these five plates with cation chloride co-transporter probe, five positive signals were found in three plates: one plaque in plate 1, one in plate 4 and 5 in plate 5. In Fig. 3 below the positive plaques for one set are indicated with arrows in both replicas.

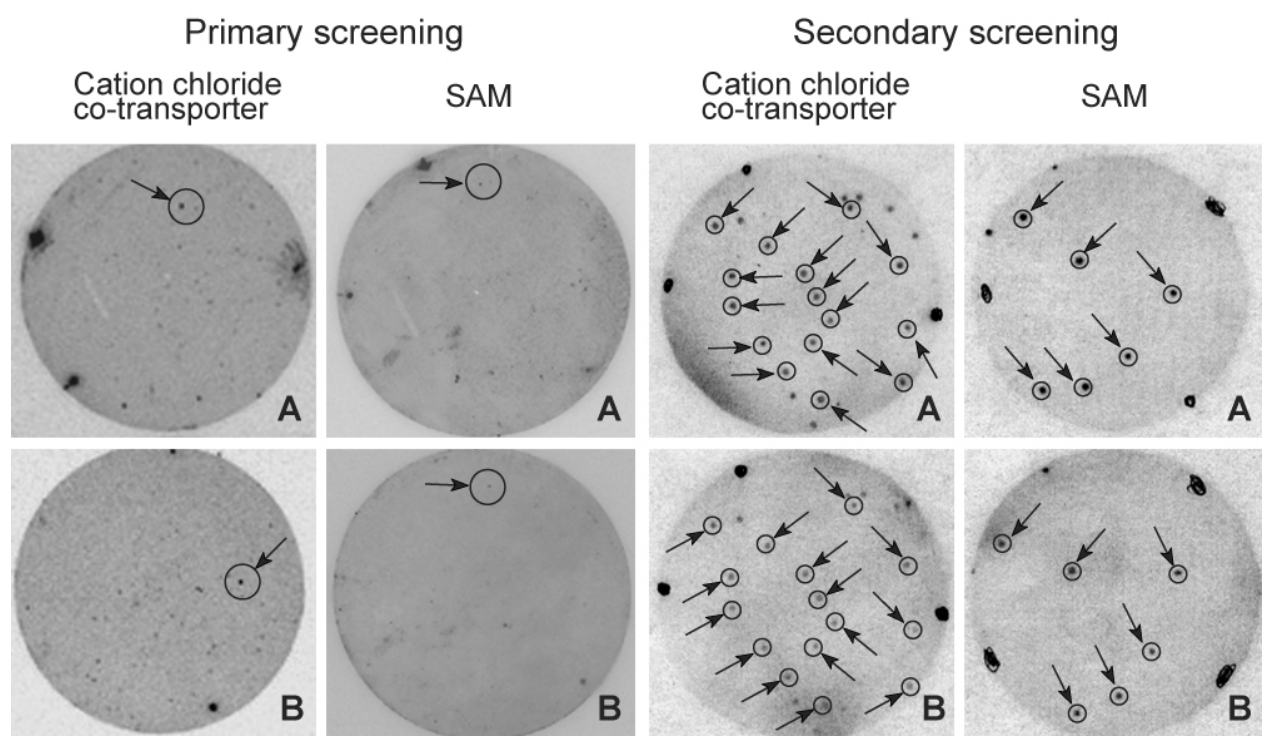

Fig. 3. Positive plaques of cation chloride co-transporter and SAM after primary and secondary screening, arrow indicating some of the positive plaques.

Primary screen result of SAM: Replicas of the same five plates were used for screening with the SAM probe. After screening 3 positive signals were found in three plates : one plaque in plate 2 , one in plate 3 and the last one in plate 4 . Each positive signal was confirmed by both replicas of each plate. In Fig. 3, positive plaques for one set are indicated in both replicas with arrows.

Secondary screening of both probes: Each positive plaque lifted from the primary screening was passed through secondary screening with the same probes. After secondary screening each positive plaque was amplified more than once and these positive plaques were found to be very distinct (Fig. 3). Since the $100 \mathrm{~mm}$ Petri dish used for plating had only 100 - 200 plaques, it was very easy to locate the individual positive plaques. The positive signals were confirmed by the two replicas of one plate. Only very easily separateable positive plaques were 
picked out from the agar plate and dissolved in SM buffer. Each positive single plaque was collected in individual Eppendorfs. A drop of chloroform was added to each Eppendorf to prevent growth of other bacteria.

The positive plaques from the secondary screening were pure enough for isolation. Therefore, plaques were not screened for a third round. The desired DNA sequences of cation chloride co-transporter and SAM genes will be isolated from lambda clones, using lambda DNA isolation kit from Qiagen. The DNA will be sequenced and sub-cloned into TAC vectors for Agrobacterium-mediated transformation of these large inserts into salt sensitive rice.

\section{Acknowledgements}

GCP (Generation Challenge Program) fellowship, 2006 was awarded to Suhaila Rahman for this research project, which is gratefully acknowledged. Thanks to Ellen Tumimbang for the probes (cation chloride co-transporter and SAM) which were designed and sequenced by her.

\section{References}

Akbar M, Gunawardena IE and Ponnamperuma FN (1986a) Breeding for soil stresses. In: Progress in rainfed lowland rice. International Rice Research Institute, Manila, The Philippines, pp. 263-272.

Akbar M, Khush GS and Hillerislambers D (1986b) Genetics of salt tolerance in rice. In: Progress in rainfed lowland rice. International Rice Research Institute, Manila, The Philippines, pp. 399-409.

Bohra JS and K Dörffling (1993) Potassium nutrition of rice (Oryza sativa L.) varieties under NaCl salinity. Plant \& Soil 152: 299-303.

Bonilla P, Dvorak J, Mackill D, Deal K and Gregorio G (2002) RFLP and SSLP mapping of salinity tolerance genes in chromosome 1 of rice (Oryza sativa L.) using recombinant inbred lines. Philippine Journal of Agricultural Science, 85: 68-76.

Cantrell RP and Reeves TG (2002) The rice genome: The cereal of the world's poor takes center stage. Science 296(5565): 53.

Doyle JJ and Doyle J L (1990) Isolation of plant DNA from fresh tissue. Focus. 12: 13-15.

Elahi CMF, Seraj ZI, Rasul NM, Das KC, Biswas K Salam MA, Gomosta AR, Tumimbang E, Adorada D, Gregorio G and Bennett J (2004) Breeding rice for salinity tolerance using the Pokkali allele: finding a linked DNA marker. In vitro Culture, Transformation and Molecular markers for Crop Improvement. Islam AS (Ed.) Science Publishers, Inc, USA. pp. 157-170.

Flowers TJ and Flowers SA (2005) Why does salinity pose such a difficult problem for plant breeders? Agric. Water Management 78: 15-24 
Gregorio GB, Senadhira D, Mendoza RD, Manigbas NL, Roxas JP and Guerta CQ (2002) Progress in breeding for salinity tolerance and associated abiotic stresses in rice. Plant Breeding, Genetics, and Biochemistry Division, International Rice Research Institute, DAPO Box 7777, Metro Manila, Philippines.

IRRI (1996) Standard evaluation system manual. International Rice Research Institute, Los Banos, The Philippines.

Kawasaki S, Borchert C, Deyholos M, Wang H, Brazille S, Kawai K, Galbraith D and Bohnert H J (2001) Gene Expression Profiles during the Initial Phase of Salt Stress in Rice. The Plant Cell 13: 889-905.

Khush, G S (1999) Green revolution: Preparing for the 21st century. Genome 42: 646-655.

Lambda FIX II/Xho I Partial Fill-In Vector Kit: Xho I/Gigapack III XL Packaging Extract (Stratagene) and Klenow Fill-In Kit (Stratagene).

Lee KS, Choi WY, Ko JC, Kim TS and Gregorio GB (2003) Salinity tolerance of japonica and indica rice (Oryza sativa L.) at the seedling stage. Planta 216(6): 1043-1046.

Lisa LA, Seraj ZI, Elahi CMF, Das KC, Biswas K, Islam MR, Salam MA and Gomosta AR (2004) Genetic variation in microsatellite DNA, physiology and morphology of coastal saline rice (Oryza sativa L.) landraces of Bangladesh. Plant \& Soil 263: 213-228.

Qu S, Coaker G, Francis D, Zhou B and Wang GL (2003) Development of a new transformation-competent artificial chromosome (TAC) vector and construction of tomato and rice TAC libraries. Molecular Breeding 12: 297-308.

Ren ZH, Gao JP, Li LG, Cai XL, Huang W, Chao DY, Zhu MZ, Wang ZY, Luan S and Lin HX (2005) A rice quantitative trait locus for salt tolerance encodes a sodium transporter. Nat. Genet. 37: 1141-1146.

Senadhira D, Neue HU and Akbar M (1994) Development of improved donors for salinity tolerance in rice through somaclonal variation. SABRAO J. 26(1-2): 19-25.

Thomson MJ, Ocampo de M, Egdane J, Katimbang M, Rahman MA, Singh RK, Gregorio GB and Ismail AM (2007) QTL Mapping and Marker-assisted Backcrossing for Improved Salinity Tolerance in Rice. BioAsia (www.bioasia-2007.com), Supplement Papers. pp. 6-12.

Tyagi AK and Mohanty A (2000) Rice transformation for crop improvement and functional genomics. Plant Sci. 158: 1-18.

Young ND and Tanksley SD (1989) RFLP analysis of the size of chromosomal segments retained around the Tm-2 locus of tomato during backcross breeding. Theor. Appl. Genet. 77: 353-359. 